\title{
Additive Focus and Additional Functions of Karbi (Tibeto-Burman) $=t \bar{a}^{1}$
}

\author{
LINDA KONNERTH \\ University of Oregon
}

\section{$1 \quad$ Introduction}

Karbi is a tonal ${ }^{2}$ Tibeto-Burman language with about half a million speakers, most of them living in the Karbi Anglong district of Assam and adjacent areas in Northeast India. It is an agglutinating, verb-final language.

This study examines different functions of the enclitic $=t \bar{a}$ in Karbi with the goal to contribute to a cross-linguistic typology of additive focus markers. Karbi $=t \bar{a}$ translates as the English additive particle 'also,' but additionally occurs in at least five other constructions, as laid out in this paper. Specifically, the data show that besides 1) marking additive focus, =tā may 2) function as a coordinator, or 3) indicate the scalar additive meaning 'even.' Through that function $=t \bar{a}$ also appears to be part of concessive conjunctions. Furthermore, $=t \bar{a}$ functions 4) to mark universal quantification. Perhaps related to this latter function, $=t \bar{a}$ occurs seemingly just idiomatically with certain adverbs. Attaching to verbs, this enclitic occurs 5) in a copy verb construction that seems to have an intensifying function. Finally and most intriguingly, $=t \bar{a}$ functions 6) as a discourse structuring device.

Karbi $=t \bar{a}$ shares its enclitic position with three other markers, all of which occur on noun phrases to signal their discourse status, and also occur on verbs or predicates and adverbs. These three markers are 1) $=k e$, which appears to mark a topic-type discourse status - yet awaiting a more detailed pragmatic analysis - and further 2) $=s i$ and 3) its irrealis counterpart =le, which both mark contrastive focus. Karbi $=t \bar{a},=k e,=s i$, and $=l e$ form a paradigm in that one particular constituent may only contain one of the four. However, within the same clause, these markers can to some degree co-occur on different constituents. On noun

\footnotetext{
${ }^{1}$ Thanks to Scott DeLancey as well as the UO FieldLing Workgroup and participants of BLS 38 for insightful comments. I would also like to especially acknowledge my collaborator Mr. Sikari Tisso of the Karbi grammar project, who has devoted endless amounts of his time to the project, as well as all members of the Karbi community who have contributed to the project. Any errors are my responsibility. Support for this project has been provided by NSF grant \#BCS-0951749.

2 The three tones of Karbi are low (indicated by '), mid (indicated by ${ }^{-}$), and high (indicated by ').
} 


\section{Linda Konnerth}

phrases, the markers are not associated with syntactic roles, but purely indicate pragmatic status.

In the linguistic literature on Karbi, Grüßner (1978:61) mentions $=t \bar{a}$ 'also' in a section on nominal emphatic suffixes along with $=l e,=k e$, and $=s i$. Although he gives examples of $=t \bar{a}$ in several different functions, he does not explore these further. Grüßner does, however, offer another syntactic criterion that helps define the differences between the verbal functions of $=t \bar{a},=l e,=k e$, and $=s i$, which has to do with whether they follow final predicates or non-final verbs.

The article is structured as follows: Section 2 discusses the literature on crosslinguistic functions of additive particles. This is followed by the main body of the article in Section 3, where the different functions of $=t \bar{a}$ are discussed in six subsections. Section 4 provides a preliminary quantitative perspective on the distribution of $=t \bar{a}$ functions, followed by a conclusion in Section 5 . The present case study is based on an approximately 10,000 word corpus of primary Karbi data collected between 2009 and 2011 in Karbi Anglong, Northeast India.

\section{Cross-linguistic Functions of Additive Particles}

Additive particles have not been explored cross-linguistically in their own right much, the notable exception being König (1991) in his pioneering comparative work on focus particles, which is largely based on European languages, but includes observations on other languages as well. König establishes functional clusters that additive particles mark or are part of marking in various languages, including the marking of coordination; indefinite pronouns such as 'whoever' in combination with interrogative pronouns; and concessive conjunctions such as 'even though' in combination with other elements. With respect to the crosslinguistically common syncretism between regular additive meaning (like 'also') and scalar additive meaning (like 'even'), König says that "unspecific additive particles like G[erman] auch that are compatible with both scalar and non-scalar contexts can be found in a wide variety of languages (1991:64)."

Several contributions in Haspelmath's (2004a) volume on coordinating constructions confirm the link between conjunction and additive focus as already pointed by König (1991). Especially Gil's (2004:389) article on Riau Indonesian contains an interesting discussion of the different functions of a morpheme functioning as a conjunction and additive particle in this language, which also includes universal quantification to mean 'all' or 'every' (cf. also Haspelmath 1997). Likewise, an interesting case study is Emeneau (1980), which lays out five different "usages" of the Sanskrit additive particle api and of additive particles in other Indo-Aryan and Dravidian languages in India. These functions overlap with the functions of $=t \bar{a}$ in marking the additive particle ('also'), the coordinator ('and'), the scalar additive particle ('even'), as well as universal quantification 
(“"totalizing' or 'summing") and based on that also indefinite pronouns when occurring on interrogative pronouns.

What we can summarize at this point is that the connection between additive (scalar) particles and conjunctions on the one hand, and universal quantification on the other hand appears to be highly recurrent in language after language. In addition, there appear to be other related functions that are perhaps less commonly part of the functional range of additive particles such as marking sociative and sameness (cf. Gil 2004), which, however, are not found in Karbi.

The descriptive cross-linguistic literature on additive particles that function as discourse structuring devices is sparse and scattered, but there do seem to be commonalities between strategies in quite different languages, both from a geographic and a genetic point of view. In addition, more theoretical research on German has discussed the stressed variant of the additive particle auch as a marker of contrastive topics (Krifka 1999; Sudhoff 2010).

Additive particles with larger discourse functions have been described for Indo-European, Niger-Congo and Afroasiatic languages. In the Western Iranian languages Western Gilaki (Rashti) and standardized colloquial Persian, we find =(h) cem 'also; even; and, but' used "as a way to mark a new theme (Stilo 2004:323-6, citing Lazard (1989:281))." In the Kwa (Niger-Congo) language Avatime, the additive particle tsye is not only used as a focus but also as a topic marker, often in conjunction with a topic-switch (van Putten 2011). Similar cases have been made for the Afroasiatic languages Gawwada (Tosco 2010) and Amharic (Demeke \& Meyer 2008).

The literature reviewed here describes different discourse functions of additive particles, among them 'marking a new theme,' 'topic-switch,' 'contrasting topic,' and 'contrastive focus.' The purpose of this article is not to compare these different notions and to argue for the exact status of Karbi $=t \bar{a}$ vis-à-vis these terms - this is a matter for future research - but to produce a case study that contributes to a functional typology of additive particles.

\section{$3 \quad$ Additive functions of Karbi $=t \bar{a}$}

This section presents the main body of this article and documents the following functions of $=t \bar{a}$ : 3.1 ) additive particle; 3.2) coordination; 3.3) scalar additive particle; 3.4) universal quantification; 3.5) intensifier; 3.6) discourse marker. I will discuss definitions of each function at the beginning of each subsection.

\section{1 $=t \bar{a}$ as simple additive particle 'also'}

As a starting point, we may use a somewhat simplified definition and say that additive particles "express that the predication holds for at least one alternative of the expression in focus (Krifka 1999:111)." This definition captures a lot of the 


\section{Linda Konnerth}

instances of additive $=t \bar{a}$, although not all as will be clear from examples below. When functioning as the simple additive particle 'also', =ta does "not induce an ordering" (König 1991:60) in relationship to the alternatives, for which the respective predication holds; this distinguishes it from the scalar additive meaning of 'even' (cf. Section 3.3).

Example (1) shows $=t \bar{a}$ functioning to presuppose that the predication rongkèr $p u$ dō 'celebrate the Rongker' holds for another participant, which represents an alternative to tekè atūm 'the tigers.' Here, this presupposed alternative is 'humans,' or more specifically, the Karbi people. The parallel assertion that 'humans/the Karbi people celebrate the Rongker' is not explicitly stated in the preceding sentence, but is known as general knowledge within the Karbi community.

(1) =tā meaning 'also' with topic marker =ke in the same clause hako arnike... teke atumta rongker pu do tangho

hakó arnì=ke [tekè a-tüm=tā] [rongkèr pu] dō tànghò then day $=$ TOP tiger POSS-PL=also PN QUOT exist hearsay 'at the time (in the old days) tigers also (like humans) celebrated the Rongker' [HK, TR 035]

Interesting to note about example (1) is also that the topic marker $=k e$ occurs in the same clause, but on a different noun phrase (NP), which is used adverbially: hako arnike 'in the old days.' This provides evidence for this particular cooccurrence possibility between $=t \bar{a}$ and the discourse structuring enclitic $=k e$.

Example (2) shows an interesting scope issue: $=t \bar{a}$ may attach to an NP while having scope over the whole clause. This example is from a folk tale, and specifically from a point in the story, at which a tiger is running off. Example (2) is produced by a listener - indicated here by curly brackets - asking the storyteller whether the tail of the tiger was standing up while the tiger was running, simply to make the storyteller include a more visual description as part of telling the story.

(2) Scope: $=t \bar{a}$ attaching to NP even when scope is over whole clause \{armeta jarherjima\} [...] arm $\bar{e}=t \overline{\boldsymbol{a}}$ jàr-hèr-jí=ma\} tail=also be.standing.up-high.up-IRR $2=\mathrm{Q}$ ' $\{$ and its tail might have been standing up, too?\} [...]' [HK, TR 117]

Here, $=t \bar{a}$ doesn't mean that the tail in addition to say the ears of the tigers were standing up - which would be NP scope - but that in addition or as part of the running, the tail was standing up, meaning that $=t \bar{a}$ here has clausal scope. The $=t \bar{a}$ in (2) is perhaps best translated with combining 'and' and 'too' in 
English, which already gives an idea of the fuzzy boundary between additive and coordinating functions, which is explored further in the next section.

\section{2 $=t \bar{a}$ as bisyndetic coordinator}

Coordination may be defined to refer to the function of syntactically conjoining at least two, more or less symmetrical constituents to form a new constituent, following similar definitions by Mithun (1988) and Haspelmath (2004b). This is different from the additive particle function of 'also', which more loosely "point[s] out a parallelism between otherwise separate entities (Mithun 1988:340)." The additive particle links a constituent to previously mentioned information in the discourse or general knowledge, whereas a coordinator is a syntactic device to link constituents. Although $=t \bar{a}$ is not used for coordinating NPs, ${ }^{3}$ it is used in other coordinating constructions, and constructions intermediate between additive and coordinating functions, as shown in this section.

The coordinating function of $=t \bar{a}$ is restricted to higher-level constituents (verb phrases and clauses, not noun phrases), even though there are examples, where $=t \bar{a}$ at least semantically coordinates subject noun phrases as in (3). ${ }^{4}$

(3) $=t \bar{a}$ as a coordinator across clauses

[...] Bey Ki'ik abangta ahem arit dolo

$\begin{array}{llllll}\text { [Bēyy } & k V \text {-ik } & a b a ̀ n g=t \bar{a}] & a-h \bar{e} m & a-r i ́ t & d \bar{o}-l \grave{o} \\ \text { PN } & \text { NMLZ-be.black } & \text { NPD=also } & \text { POSS-house } & \text { POSS-field } & \text { exist-RL }\end{array}$

Bey Ke'et abangta ahem arit dolo

Bey Ronghang abang akibi abangta ahem arit dolo

'[...] Bey the Black had his (own) house and property, Bey the Fair likewise had his (own) house and property, and Bey Ronghang, the young one, also had his (own) house and property' [WR, BCS 004]

In this construction, the predicate - here ahem arit dolo 'had his (own) house and property' - needs to be repeated each time so that from a syntactic perspective $=t \bar{a}$ coordinates these clauses instead of the subject NPs, which form the coordinated list that is marked bisyndetically by $=t \bar{a}$ on each one.

Typologically, the construction in (3) seems odd because the subjects of the three clauses are semantically coordinated without actually being syntactically

\footnotetext{
${ }^{3} \mathrm{NP}$ coordination is achieved by either simple juxtaposition or monosyndetic use of comitative/instrumental =pen 'with' (or by using lapen 'and (<this=with)' as a coordinator).

${ }^{4}$ Note that only the first of three consecutive clauses is interlinearized due to space constraints and their parallel structure.
} 


\section{Linda Konnerth}

coordinated. It therefore behaves like a hybrid between the 'also' and the coordinating function: the occurrences of $=t \bar{a}$ indicate more than just a semantic link but less than a syntactic coordination construction. Evidence that the three clauses form more than just a semantic link is not only that they follow in immediate sequence, but they also form a narrative unit, since new narrative units are marked by a word like ánke 'and then,' which does not intervene here.

A more prototypical example for the coordinating function of $=t \bar{a}$ is (4). Here, $=t \bar{a}$ may reasonably be argued to coordinate verb phrases, as it occurs bisyndetically on the objects of each verb phrase. The exact same construction exists in Hakha Lai, a not too distantly related Tibeto-Burman language (Peterson and VanBik 2004:348).

(4) More prototypical coordinating function of $=t \bar{a}$ langta junlong, anta cholong
[lāng=tā
jùn-lōng]
$[\grave{a} n=t \overline{\boldsymbol{a}}$
chō-lōng]
water $=$ also.COORD drink-get.to rice $=$ also.COORD eat-get.to
'[...] they got to drink water and they got to eat rice [...]' or 'they got to eat and drink' [KK, BMS 056]

This structural type of a clause coordinating construction, where the coordinator occurs on NPs and therefore internally to the clausal constituents that it coordinates, might seem unusual but is in fact one of the general types recognized by Haspelmath (2004b:9).

\section{3 $=t \bar{a}$ as scalar additive particle 'even'}

Following again Krifka (1999:111) we may define that "[s]calar particles assert that the predication holds for the expression in focus, and presuppose that this predication is prima facie less likely than the alternative predications." In other words, scalar additive particles like 'even' not only presuppose alternatives but also rank them, hence they are additive and scalar. In (5), =tā conveys both: the witch taking one step has an infinite number of alternatives, i.e. taking two, three, or any number of steps. Among an infinite number of steps, taking one step is assumed to be the easiest to achieve in the particular context, and therefore the likeliest, which is what is expected to be marked by a scalar additive particle in a negated clause. The use of $=t \bar{a}$ here presupposes the alternatives and ranks them.

(5) =tā meaning 'even'

hala hi'ipi abangke ekam anta kamkelang [...]

hála hì'ipi abàng=ke e-kām án=ta kàm-ke-làng

that witch $\mathrm{NPD}=\mathrm{TOP}$ one-step that.much=even step-NEG-yet

'[and then,] the witch couldn't take even one step [...]' [CST, HM 105] 
As pointed out in Section 2, 'even' particles often combine with other elements to grammaticalize as concessive conjunctions in languages across the world, which is also the etymology of 'even though' in English. Therefore, it seems anything but coincidental that we find the forms bóntā 'but' and setā/sitā 'although, but' in Karbi, where the second part of these forms is $t \bar{a}$. The table in (6) shows the concessive conjunctions in Karbi as well as data from two other Tibeto-Burman languages (from Nepal): Darma (Willis 2007) and Dhimal (King 2009). King (2009:222) even points out that the Dhimal concessive conjunction is a combination of the sequential marker -tey and the additive particle buy, although he hypothesizes this to be an Indo-Aryan calque as the same construction is found in Nepali. It is, however, interesting that Karbi setā/sit $\bar{a}$ might have the same etymology, since $-s i$ is the non-final or sequential marker.

(6) Link between concessive conjunctions and additive particles

\begin{tabular}{|c|c|}
\hline Karbi & Other Tibeto-Burman languages \\
\hline bóntāa 'but' & $\begin{array}{l}\text { perhaps Darma (Willis 2007): } \\
\text { lekin 'but' < le 'also' }+\mathrm{X}\end{array}$ \\
\hline $\begin{array}{l}\text { setā/sit } \bar{a} \text { 'but, although' } \\
(?<-s i \text { 'non-final' }+=t \bar{a} \text { 'even, } \\
\text { also') }\end{array}$ & $\begin{array}{l}\text { Dhimal (King 2009:222): } \\
\text {-tey 'SEQ' + buy 'also' for 'even } \\
\text { though' }\end{array}$ \\
\hline
\end{tabular}

The example in (7) offers a recurring construction in Karbi, where $=t \bar{a}$ appears to function as a concessive conjunction all by itself when it occurs on the quotative marker $p u$ following direct speech.

(7) $=t \bar{a}$ as 'even if' on quotative $p u$

[...] "diho!" puta, kroikredetlo

[dího $\quad p u=t \overline{\boldsymbol{a}}] \quad$ [krōi-krē-dèt-lò]

leave.me! QUOT=although agree-NEG-PFV-RL

‘[...] although she said “hey, leave me!”, he didn't agree' [KK, BMS 080]

\section{$3.4=t \bar{a}$ marking universal quantification}

Several labels are already in use to describe similar concepts for this next function of Karbi =tā: "“totalizing' or "summing"” (Emeneau 1980:199), "universal quantification" (Gil 2004:389), "dismissive construction" (Post 2007:341), and “categorical propositions" (King 2009:263). Here, I will adopt Gil's (2004) term "universal quantification" for describing this function of Karbi $=t \bar{a}$.

For this function, $=t \bar{a}$ occurs typically either on generic nouns or numerals, but may also occur on entire noun phrases, especially along with the quantifying particle án 'all, this much.' An example in which $=t \bar{a}$ attaches to a generic noun is 


\section{Linda Konnerth}

(8), where ját 'type' becomes játtā, which in a positive clause would mean 'everything', and in the negated clause here 'nothing' / 'anything.'

(8) Marking universal quantification: =tā on general noun ját 'type' jatta manme, jirpo, ne pudun'etlo [ját $=t \overline{\boldsymbol{a}} \quad$ mán-mē] jūrpō nè pù-dūn-ét-lò type $(<\mathrm{IND})=\mathbf{U Q}$ become/happen-NEG friend 1EXCL say-JOIN-PRF-RL 'nothing will happen, friend, I've already done the talking' [HK, TR 141]

In (9), $=t \bar{a}$ attaches to the numeral to indicate that the set is complete, i.e. 'both of them' refers to two friends, and there are only these two friends in the story.

(9) Indicating all of a specific set ha thengpi angsongsi dolo, banghinita há thengpī angsóng=si dō-lò bàng-hiní=tā over.there $(<\mathrm{KHJ})$ tree/wood high.up $=$ FOC exist-RL CLF-two $=\mathbf{U Q}$ 'up there on the tree top they are there, both of them' [HK, TR 152]

This use of $=t \bar{a}$ as in (9) seems to follow the same principle as discussed by Emeneau that "[t]his summation is found in references back to a group once it has been defined, or in reference to a 'natural' group (the two eyes, all the gods, the directions, etc.) (1980:200)."

Example (10) shows that $=t \bar{a}$ for this function may also attach to a whole NP, where in this case distributive universal quantification is expressed.

(10) Distributive universal quantification: 'each and every one' laso aphike asitin akhei aphanta

[lasō aphī=ke] [a-isī-tín a-khéi aphān=tā]

this after $=$ TOP POSS-one-each POSS-community $\mathrm{PO}=\mathbf{U Q}$

isisi ahem kikimpi do hadak [...]

is $\bar{\imath} \sim i s \bar{\imath} \quad a$-hèm $\quad k V$-kìm-pì dō hádāk

one DISTR.PL POSS-house NMLZ-build-BEN exist there

'after that, there was one house built for every tribe there [...]' [SiT, HF

045]

Another interesting parallel to findings from Emeneau's work on Indo-Aryan and Dravidian languages emerges from cases where the additive particle is "redundantly used with [...] 'all' [...] and [...] 'always' (Emeneau 1980:200)." The same phenomenon is present in the Karbi forms kái $(=t \bar{a})$ 'always', arnìváng $(=t \bar{a})$ 'every day', as well as in the cooccurrence of $=t \bar{a}$ with the quantifying enclitic =án 'all, this much.' These adverbs clearly have the semantics of temporal 
universal quantification, although this is perhaps less clearly the case for some other forms that seem to carry $=t \bar{a}$ idiomatically as well: $m o ́=t \bar{a}$ 'future; in the future', and $h a k \dot{b}=t \bar{a}$ (also reduplicated $h a k \dot{ } \sim k \dot{o}=t \bar{a}$ ) 'long ago; in the old days.' However, it is not implausible that future and past would be conceptualized as infinite in the temporal domain (like 'in all of the future' and 'in all of the old days'), which then would explain why $=t \bar{a}$ attaches to these forms.

\section{5 $=t \bar{a}$ in intensifier verb construction: STEM $=t \bar{a}$ STEM-inflection}

In this construction, $=t \bar{a}$ occurs on a copy verb stem immediately preceding the main inflected predicate, as in (11). The function of this construction appears to be intensifying.

(11) STEM=tā STEM-inflection construction

anke.... paprapta paprap'olo [...]

ánke $\quad \boldsymbol{p} V$-prà $\boldsymbol{p}=t \overline{\boldsymbol{a}} \quad \boldsymbol{p} \boldsymbol{V}$-pràp-ò-lò

and.then CAUS-be.quick=INT CAUS-be.quick-much-RL

'and then, they did everything very quickly [...]' [HK, TR 160]

The same formal construction exists in Hakha Lai (Tibeto-Burman), where its function, however, is coordinating, i.e. this copy verb stem construction is found in two consecutive intransitive clauses and coordinates them (Peterson and VanBik 2004:350). The same type of coordinating construction is also found in Chechen (Haspelmath 2004a:9, quoting Good (2003:134)).

\section{6 $=t \bar{a}$ as a discourse structuring device}

The most intriguing function of $=t \bar{a}$ is where it structures the larger discourse within a text by marking reactions of participants towards preceding events or actions. The examples given here are selected so that the turns indicated by $=t \bar{a}$ will hopefully become clear from the smaller context of the preceding clause without requiring a renarration of the complete respective stories. An example is a part of a Karbi folk story about a frog and an ant given in (12a-c).

(12a) Frog and Ant Story [...] chongho ami korlut [chonghō a-mí] kòr-lùt frog POss-buttocks bite-enter '[...] (the ant) bit the frog's butt with its teeth entering' [RBT, ChM 017] 


\section{Linda Konnerth}

$(12 \mathrm{~b})=t \bar{a}$ marking a reaction or direct consequence - subject change amat chonghota chonthap chonphrulo amāt chonghō=tā chón-tháp chón-phrú-lò and.then frog=DM jump-everywhere jump-everywhere-RL

kesolo... karlesibongpo adon chonrai

kV-sò-lò karlēsibóng-pō a-dón chón-rài

NMLZ-hurt-RL sp.squirrel-M POSS-bridge jump-solid.object.breaking 'and then, the frog was jumping around because it was hurt, and it jumped on the ladder of the squirrel and it broke' [RBT, ChM 018]

(12c) $=t \bar{a}$ marking a reaction or direct consequence - subject change amat karlesibongpota... aning thilo [...] amāt karlèsibóng- $\bar{p} \bar{o}=t \overline{\boldsymbol{a}}$ a-ning thī-lò and.then sp.squirrel-M=DM POSS-mind be.short-RL 'and then, the squirrel... got angry [...]' [RBT, ChM 019]

(12a) introduces the event that leads to one consequence after another: the ant bites the frog. As a consequence, (12b) states that the frog jumps around and accidentally breaks the ladder of the squirrel, which leads to the squirrel getting angry in (12c). This chain reaction of one thing leading to the next is the whole idea behind the story and there are more events that set off in the same way after the squirrel gets angry. Structurally, the way these reactions of first the frog, then the squirrel, and so on, are marked is by adding $=t \bar{a}$ to the respective participant as it reacts to what just happened to it. It is this marking of a story participant as it reacts to something another story participant just did which is the discourse function of $=t \bar{a}$ here.

What is also noteworthy about $(12 \mathrm{~b}-\mathrm{c})$ is that the participant marked by $=t \bar{a}$ becomes the new subject or agent (perhaps topic, but that depends on further pragmatic analysis) compared to the preceding clause. This is different from (13), where the subject is the same across both clauses, and what is marked by $=t \bar{a}$ appears to be the immediate cause-result relationship between the two clauses: because the friend sees the money, therefore he becomes happy.

(13) Consequence resulting from previous statement - same subject hala tangka atibuk theklonglo anke

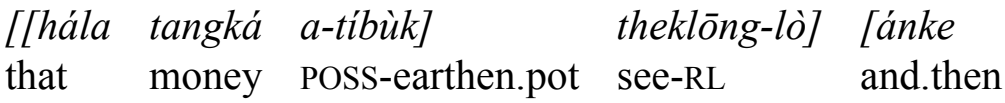

hala ajirpota aning arong'olo tangho [...] [hála a-jirpò $=\mathbf{t a}] \quad[a-n \bar{n} g \quad$ aróng-ò-lò] tànghò] that POSS-friend=DM POSS-mind be.happy-much-RL hearsay 
'(he) saw those money pots, and so that friend became very happy [...]' [HK, TR 161]

Example (14) shows that $=t \bar{a}$ may also occur on a primary object while otherwise marking the same function of indicating a consequence: since the king in this story recognizes that the so-called Hingchong siblings are his children, he calls them home. The $=t \bar{a}$ here does not have an additive function, since there are no other children involved in this story.

(14) Consequence - same subject; $=t \bar{a}$ on primary object o nangtum nesolo pusi... laso aHingchong

[[o nang-tūm ne-osōolo] pu-si] [[lasō a-Hingchòng AFF 2-PL my-child=AST say-NF this POSS-PN

musoso aphanta hem chehang ponlo

musōsō] aphān=tā] hēm che-háng-pòn-lò

siblings.diff.gender.dual $\mathrm{PO}=\mathbf{D M}$ house RR-call-take.away-RL

' $<$ o, you are my children $>$, he said, and so he called these two Hingchong siblings home' [CST, HM 106]

Although across the two clauses given in (14) - i.e. the direct speech followed by the simple declarative clause - the subject does not change as it is the king in both cases, $=t \bar{a}$ might still function as a general topic switch indicator since the clauses preceding the ones in (14) are about two other protagonists, namely the two wives of the king, one a witch, the other a Karbi woman. The Hingchong siblings are the Karbi wife's children, whereas the witch claims that that is a lie. Therefore both wives are tested to see who speaks the truth, and the clause directly preceding (14) establishes that the witch had lied, whereupon (14) affirms that therefore, the Hingchong siblings are in fact the king's children. In that sense, (14) does indicate a larger turn in the story, namely the turn between the testing of the wives and the resulting recognition of the siblings as the king's children.

Lastly, a typical use of the discourse function of $=t \bar{a}$ is after the end of direct speech, where it marks a participant as reacting or responding to the preceding direct speech. An example is (15), where the dog gives Bamonpo a command, and Bamonpo in turn reacts by agreeing. This shows that $=t \bar{a}$ does not always mark a major turning point, but that it perhaps instead indicates a change in participant viewpoint, which may support an analysis in terms of a topic-switch for a future discourse-pragmatic analysis of this function of $=t \bar{a}$. 


\section{Linda Konnerth}

(15) "Topic"-switch - reaction to preceding direct speech nangdunle nangdunnoi ho pulo tangho $[$ [ nang=dùn=le $\quad$ nang=dùn-nōi $\quad$ ho] pù-lò tànghò] anke bamonpota $<m h>$ kisung abidi [ánke bamón-p $\bar{o}=t \overline{\boldsymbol{a}} \quad k V$-sùng a-bidí and.then wise.person $(<\mathrm{IND})-\mathrm{M}=\mathbf{D M} \quad$ NMLZ-be.difficult $\quad$ POSS-wit

kijut'ong amat kroidunkoklo kV-jūt-óng] [amāt krōi-dūn-kòk-lò] NMLZ-finish-be.much and.then agree-JOIN-absolutely.required-RL "“[...] Just make sure to join me", (the dog) said, and Bamonpo was troubled and at his wit's end, and he agreed' [KK, BMS 035-6]

Note also in (15) that the first clause contains an irrealis version of the intensifying verb construction discussed in Section 3.5, where the first copy verb stem occurs with the irrealis focus particle $=l e$ instead of $=t \bar{a}$.

\section{$4 \quad$ Preliminary quantitative perspective}

In an approximately 3,800 word partial corpus of the whole text corpus including the two longest, one medium-sized, and one short folk story, two from different speakers and two from the same speaker - there were 131 total occurrences of $=t \bar{a}$ as seen in (16). These were categorized according to the respective functions as discussed in this article, excluding 16 uncertain cases, which were left uncategorized. For the remaining 115 occurrences, the discoursemarking and additive functions were the most frequent ones at 39 and 28 occurrences. Note that the functions were unevenly distributed across the four different texts, as in the HK_TR text, there were more occurrences of the additive than the discourse function (19 and 11, respectively), whereas in the KK_BMS text - which is comparable in length - the frequency relationship between these two functions is reversed with 9 and 21, respectively. Although the very different numbers of $=t \bar{a}$ occurrences for the different functions across the four texts underscore how preliminary the quantitative perspective provided here is, there is still an interesting tendency emerging here with regard to speaker variation: Whereas it seems that speakers HK and SeT use $=t \bar{a}$ generally not as much, speaker KK has overall higher numbers of $=t \bar{a}$ occurrences and uses $=t \bar{a}$ especially in its discourse function. Again, these are very preliminary observations, but make for interesting directions for future research into the distribution of additive particle functions and inter-speaker variation. 
(16) Frequency distribution of functions

\begin{tabular}{|c|c|c|c|c|c|}
\hline $\begin{array}{l}=t \bar{a} \\
\text { functions }\end{array}$ & $\begin{array}{l}H K \_T R \\
(\sim 1,500 \\
\text { words) }\end{array}$ & $\begin{array}{l}\text { KK_BMS } \\
(\sim 1,300 \\
\text { words })\end{array}$ & $\begin{array}{l}\text { KK_CC } \\
(\sim 330 \\
\text { words })\end{array}$ & $\begin{array}{l}\text { SeT_MTN } \\
(\sim 700 \\
\text { words) }\end{array}$ & $\begin{array}{l}\text { TOTAL } \\
(\sim 3,830 \\
\text { words }) \\
\end{array}$ \\
\hline also & 19 & 9 & --- & --- & 28 \\
\hline COORD & --- & 8 & --- & --- & 8 \\
\hline even & 4 & 1 & 3 & 1 & 9 \\
\hline although & --- & 6 & --- & 1 & 7 \\
\hline UQ & 4 & 8 & 1 & 4 & 17 \\
\hline INT & 2 & 3 & 1 & 1 & 7 \\
\hline DM & 11 & 21 & 4 & 3 & 39 \\
\hline$<$ uncertain $>$ & $<3>$ & $<7>$ & 3 & $<3>$ & $<16>$ \\
\hline$T O T A L=t \bar{a}$ & 43 & 63 & 12 & 13 & 131 \\
\hline
\end{tabular}

\section{Conclusion}

There are (at least) two major questions - and directions for future research that arise as a result of surveying the different functions of $=t \bar{a}$. One is the question of whether all these different functions are really marked by just one $=t \bar{a}$ morpheme, or whether there is more than just one morpheme from a synchronic perspective. One observation that suggests that here again inter-speaker variation may play a role comes from working with two different language consultants on analyzing the KK_BMS text. In one example, speaker KK uses $=t \bar{a}$ twice in the same clause, once in the universal quantification function and once in the additive function. This seemed acceptable to one consultant, but not to the other - perhaps because for one, this was the same morpheme that should not be used twice in the same clause, whereas these were two different morphemes for the other.

The other major question and direction for future research, as mentioned before, is a more detailed pragmatic analysis of the discourse function. However, there is also a syntactic component that awaits further analysis, which involves the exact relationships between $=t \bar{a}$ and the other three discourse markers mentioned in the introduction: $=k e,=s i$, and $=l e$. Here I want to refer to observations about two examples from this article: first, example (1) (and also (10)), which shows that $=t \bar{a}$ may co-occur with $=k e$ in the same clause, and second, example (15), which shows that in the intensifier verb construction, $=t \bar{a}$ is replaced by $=l e$ if the predicate is in irrealis mood. This means that although technically all four markers form a paradigm in that none of them can co-occur on the same NP, there is also a sense of a separate clausal level, on which $=t \bar{a}$ has a syntagmatic relationship with $=k e$ but still a paradigmatic relationship with $=l e$. 


\section{Linda Konnerth}

\section{Abbreviations}

\begin{tabular}{|c|c|c|c|c|c|}
\hline 1 & $1^{\text {st }}$ person & EXCL & exclusive & NPD & noun phrase delimiter \\
\hline 2 & $2^{\text {nd }}$ person & FOC & focus & PL & plural \\
\hline AFF & affirmative & SUGG.IMP2 & $\begin{array}{l}\text { suggestive } \\
\text { imperative } 2\end{array}$ & PN & proper name \\
\hline AST & assertive & $<\mathrm{IND}$ & from Indic & $\mathrm{PO}$ & primary object \\
\hline BEN & benefactive & INDEF & indefinite & POSS & possessive \\
\hline CAUS & causative & IMP & imperative & Q & question particle \\
\hline CIS & cislocative & IRR2 & irrealis 2 & QUOT & quotative \\
\hline CLF & classifier & $<\mathrm{KHJ}$ & $\begin{array}{l}\text { from Khasi } \\
\text { (Jaintia) }\end{array}$ & RR & reflexive/reciprocal \\
\hline COORD & coordinator & M & masculine & RL & realis \\
\hline DISTR & distributive & MID & middle & SG & singular \\
\hline $\mathrm{DM}$ & $\begin{array}{l}\text { discourse } \\
\text { marker }\end{array}$ & NEG & negative & TOP & topic \\
\hline EMPH & emphatic & NMLZ & nominalizer & UQ & universal quantifier \\
\hline
\end{tabular}

\section{References}

Demeke, Girma A. and Ronny Meyer. 2008. The enclitic - $m m$ in Amharic: Reassessment of a multifunctional morpheme. Linguistics 46(3): 607-28.

Emenau, Murray B. 1980. The Indian Linguistic Area Revisited. In M. B. Emeneau, Language and Linguistic Area, 197-249. Stanford: Stanford University Press.

Gil, David. 2004. Riau Indonesian sama: Explorations in macrofunctionality. In M. Haspelmath, ed., Coordinating constructions, 371-424. Amsterdam/Philadelphia: John Benjamins.

Good, Jeff. 2003. Clause combining in Chechen. Studies in Language 27(1): 11370.

Grüßner, Karl-Heinz. 1978. Arleng Alam, die Sprache der Mikir: Grammatik und Texte. Wiesbaden, Franz Steiner Verlag.

Haspelmath, Martin. 1997. Indefinite Pronouns. Oxford: Oxford University Press.

Haspelmath, Martin, ed. 2004a. Coordinating constructions. Amsterdam/Philadelphia: John Benjamins. 
Functions of Karbi (TB) additive particle $=t \bar{a}$

Haspelmath, Martin. 2004b. Coordinating constructions: An overview. In M. Haspelmath, ed., Coordinating constructions, 3-40. Amsterdam/Philadelphia: John Benjamins.

King, John T. 2008. A Grammar of Dhimal. Leiden: Brill.

König, Ekkehard. 1991. The meaning of focus particles: A comparative perspective. London: Routledge.

Krifka, Manfred. 1999. Additive Particles under Stress. In D. Strolovitch and A. Lawson, eds., Proceedings of SALT 8, 111-28, Ithaca, NY: CLC Publications.

Lazard, Gilbert. 1989. Le Persan. In R. Schmitt, ed., Compendium Linguarum Iranicarum, 263-93, Wiesbaden: Reichert.

Mithun, Marianne. 1988. The grammaticization of coordination. In J. Haiman and S. Thompson, eds., Clause combining in grammar and discourse, 331-59. Amsterdam/Philadelphia: John Benjamins.

Peterson, David A. and Kenneth VanBik. 2004. Coordination in Hakha Lai (Tibeto-Burman). In M. Haspelmath, ed., Coordinating constructions, 333-56. Amsterdam/Philadelphia: John Benjamins.

Post, Mark W. 2007. A Grammar of Galo. Melbourne: Research Centre for Linguistic Typology, La Trobe University Ph.D. dissertation.

Stilo, Donald. 2004. Coordination in three Western Iranian languages: Vafsi, Persian and Gilaki. In M. Haspelmath, ed., Coordinating constructions, 269330. Amsterdam/Philadelphia: John Benjamins.

Sudhoff, Stefan. 2010. Focus particles in German: syntax, prosody, and information structure. Amsterdam: Benjamins.

Tosco, Mauro. 2010. Why contrast matters: Information structure in Gawwada (East Cushitic). In I. Fiedler and A. Schwarz, eds., The Expression of Information Structure: A documentation of its diversity across Africa, 315-348. Amsterdam/ Philadelphia: John Benjamins.

van Putten, Saskia. 2011. Marked topics and contrast in Avatime. Paper presented at workshop "Information structure and spoken language: cross-linguistic comparative studies", Boulder, CO. 


\section{Linda Konnerth}

Willis, Christina M. 2007. A Descriptive Grammar of Darma: An Endangered Tibeto-Burman Language. Austin, TX: University of Texas Ph.D. dissertation.

Linda Konnerth

University of Oregon

Department of Linguistics

1290 University of Oregon

Eugene, OR 97403-1290

1konnert@uoregon.edu 